\title{
NOWE ŹRÓDŁA DO BADAŃ NAD FINANSAMI DIECEZJI WŁOCŁAWSKIEJ ZA RZĄDÓW BISKUPA JANA ZARĘBY
}

Sprawy finansowe zawsze należały i należą do delikatnej materii, którą ludzie i instytucje starają się zachować w pewnej dyskrecji. W Kościele, zwłaszcza w czasach komunistycznych, sprawy te $\mathrm{z}$ konieczności nie były podawane do publicznej wiadomości. Niewiele zostało na ten temat dokumentów, a te, które pozostały, zwłaszcza książki rachunkowe, są w większości tylko formalnie poprawne. Każdy proboszcz czy kuria diecezjalna w tych czasach tak rozpisywali wydatki, aby na koniec roku przychody równały się dochodom. Była to sprawa powszechnie znana.

Wśród notatek prywatnych Jana Zaręby, biskupa włocławskiego w latach 1969-1986, znalazło się też sporo zapisów dotyczących spraw finansowych ${ }^{1}$. Biskup ten miał chwalebny zwyczaj systematycznego notowania, jak rozporządzał powierzonymi do swojej osobistej dyspozycji pieniędzmi. Nie jest to wiele, ale pozwala spojrzeć na działalność biskupa pełniej, a także ocenić, jak wyglądała jego polityka finansowa. Należy też podkreślić, że nie są to wszystkie wydatki biskupa, a tym bardziej diecezji, ale tylko wybrane, może najistotniejsze w tamtych czasach.

* Ks. dr Wojciech Frątczak - adiunkt na Wydziale Teologii UMK w Toruniu, Zakład Historii Nowożytnej Kościoła, członek Towarzystwa Naukowego we Włocławku.

${ }^{1}$ Przechowywane są one w Archiwum Diecezjalnym we Włocławku. 
Wielką trudnością, na jaką natrafia badacz działalności wymagającej nakładów finansowych, jest określenie realnej wartości nabywczej ówczesnego pieniądza. Trzeba bowiem ocenić, jaką wartość w tamtych czasach przedstawiał konkretny datek, czy też ofiara. Nawet powoływanie się na wartość nabywczą, czyli cenę materiałów, produktów czy przedmiotów, też nie jest w pełni miarodajne. Cena niektórych produktów dawniej kosztownych jest dziś śmiesznie niska. Na przykład ofiarowanie komuś kilkanaście lat temu zegarka elektronicznego było czymś bardzo cennym. Dziś takie zegarki można kupić na wagę.

W Kościele wyznacznikiem wartości nabywczej pieniędzy, zwłaszcza dla duchownych, jest przeliczanie ich na stypendia mszalne. Przez całe lata były one podstawą utrzymania duchownych, szczególnie w małych parafiach i licho opłacanych urzędach kościelnych, w których zatrudnieni tam kapłani jako wynagrodzenie za pracę otrzymywali zasadniczo tylko utrzymanie - pełne lub częściowe.

W zamieszczonej poniżej tabeli zestawiono wysokość stypendiów mszalnych, jakie autor od 1974 roku czasami otrzymywał. Stypendia te należą do najniższych, tzn. takich, jakie kapłani pracujący w parafiach przekazywali do odprawienia księżom z seminariów lub innym duchownym niezatrudnionym w duszpasterstwie. Ich wysokość w parafiach była przeważnie wyższa, ale widełki między minimum a maksimum zależały od poszczególnych proboszczów, czasami też od wielkości i rodzaju parafii, tzn. wiejskiej czy miejskiej.

Tabela 1. Wysokość stypendiów mszalnych

\begin{tabular}{|r|r|l|}
\hline \multicolumn{1}{|c|}{ Rok } & Wysokość stypendium w złotych & \multicolumn{1}{|c|}{ Uwagi } \\
\hline 1974 & $50-70$ & niekiedy 100 \\
\hline 1975 & 100 & \\
\hline X 1982 & 300 & \\
\hline I 1983 & 400 & \\
\hline II 1983 & $400-500$ & \\
\hline V 1983 & 500 & w parafiach wyżej \\
\hline 1984 & 500 & \\
\hline V 1985 & 600 & \\
\hline XII 1985 & $600-1.000$ & \\
\hline 1986 & $600-1.000$ & \\
\hline V 1987 & $700-1.000$ & \\
\hline X 1987 & 1.000 & i wyżej \\
\hline 1988 & 1.000 & czasami 2.000 \\
\hline 1989 & $1.200-1.500$ & \\
\hline VIII 1989 & $2.000-3.000$ & \\
\hline X 1989 & $3.000-5.000$ & \\
\hline I 1990 & 5.000 & \\
\hline
\end{tabular}


Cd. tabeli 1.

\begin{tabular}{|c|c|c|}
\hline Rok & Wysokość stypendium w złotych & Uwagi \\
\hline || 1990 & $5.000-10.000$ & \\
\hline IV 1990 & 10.000 & \\
\hline VI 1990 & $10.000-20.000$ & \\
\hline VIII 1990 & 20.000 & \\
\hline I 1991 & 30.000 & \\
\hline VI 1991 & $30.000-50.000$ & \\
\hline XI 1991 & 50.000 & \\
\hline IV 1992 & $50.000-60.000$ & \\
\hline VII-XI 1992 & 70.000 & \\
\hline XI 1992 & 100.000 & jeden raz, okazjonalnie \\
\hline I 1993 & $70.000-100.000$ & wysokość zagranicznych: 5\$ lub 7-10 DM \\
\hline IX 1993 & $80.000-100.000$ & \\
\hline X 1993 & 100.000 & $\begin{array}{l}\text { i więcej lub zagraniczne } 7-10 \mathrm{DM} ; 1 \mathrm{DM}= \\
12.000 \text { zł na czarnym rynku }\end{array}$ \\
\hline XI 1993 & 100.000 & \\
\hline X 1994 & $120.000-150.000$ & \\
\hline || 1995 & 150.000 & \\
\hline XI 1995 & 20 lub 2.000 .000 stare & 1 zł nowy $=10.000$ zł starych \\
\hline I 1996 & 15-20 & \\
\hline 1997 & 20 & w parafiach $25-30$ \\
\hline XI 1997 & 25 & \\
\hline 1999 & 30 & \\
\hline 2006 & 30 & czasami wyższe \\
\hline
\end{tabular}

Warto nadmienić, że gwałtowna dewaluacja pieniądza sprawiała wielki kłopot wielu proboszczom, którzy przyjmowali intencje nieraz na rok z góry, a potem nikt nie chciał ich odprawiać ze względu na wielokrotny spadek wartości stypendiów, które nie gwarantowały już dziennego utrzymania. Powyższe wyliczenia niech będą pomocą w ocenie wydatków nie tylko bpa Jana Zaręby.

Biskup Jan Zaręba prowadził bardzo skromny tryb życia, a zaoszczędzone pieniądze obracał na cele diecezjalne, w tym czasie głównie na budowę kościołów. Świadectwem jego dojrzałości chrześcijańskiej jest jego testament, w którym napisał krótko: „wszystko, co posiadam, jest własnością diecezji”. Za życia mawiał też często: „co zwyczajowo otrzymuję od księży, nie otrzymuję jako Jan Zaręba, a nawet biskup Jan Zaręba, ale otrzymuję jako ordynariusz włocławski, dlatego to wszystko, co posiadam i co pozostanie po mnie po śmierci, jest własnością diecezji”. O rodzinie mówił, zwłaszcza gdy żyła jeszcze jego matka, że należy o niej pamiętać, a nawet, jeśli potrzeba, to pomagać, ale 
tzw. „ciepłą ręką”, tzn. za życia². Po jego śmierci zostało dla diecezji sporo pieniędzy, sądzę, że co najmniej równowartość budowy dwóch nowych kościołów przeciętnej wielkości.

Biskup Zaręba zapisywał wydane na różne cele sumy w kalendarzach, z których prawie wszystkie zachowały się do naszych czasów i stanowią cenne źródło poznania najważniejszych jego wydatków ${ }^{3}$. W kalendarzach tych zostały także dość skrupulatnie odnotowane ważniejsze zajęcia biskupa i dlatego stanowią one dobry diariusz jego czynności. Poza tym zawierają informacje na temat wydatków, które ponosiła Kuria Diecezjalna i biskup osobiście. Te ostatnie informacje były pisane w załączanym do kalendarza aneksie przeznaczonym na spis telefonów, stąd są zawsze w jednym miejscu i łatwo z nich korzystać.

Biskup Zaręba decydował także osobiście o rozdziale pieniędzy pochodzących z oficjalnych składek diecezji, jak fundusz konserwacji zabytków, stypendia z intencji binowanych i tac, które zbierała diecezja na budowę kościołów. Przekazując te pieniądze, zawsze pozostawiał $w$ aktach parafialnych oficjalne pisma, których kopie znajdują się $\mathrm{w}$ aktach poszczególnych parafii, ale obecnie są jeszcze niedostępne dla badaczy. Biskup prowadził też zeszyt z zapisanymi informacjami, ile poszczególni księża przekazali na jego ręce ofiar. Niestety ten zeszyt po jego śmierci dostał się w posiadanie bpa R. Andrzejewskiego i zaginął po niespodziewanej śmierci tego ostatniego.

Pieniądze otrzymywane od organizacji charytatywnych z zagranicy, najczęściej w dewizach, biskup ofiarowywał jako swoje, bo inaczej nie mógłby ich oficjalnie przekazać. Poza swoimi prywatnymi zapiskami nie uwidaczniał ich $\mathrm{w}$ żadnych sprawozdaniach.

Biskup, jadąc odwiedzić jakąkolwiek budowę kościoła, a czynił to systematycznie, zawsze zawoził proboszczowi wsparcie finansowe. Miał też zwyczaj, aby w czasie poświęcenia nowego kościoła złożyć proboszczowi na tacę pękatą kopertę, jako wsparcie na dalsze prace wykończeniowe w świątyni.

W tym czasie, w większości dzięki usilnym i długotrwałym staraniom, udało się bpowi Zarębie uzyskać zgodę na budowę kaplic i kościołów w następujących miejscowościach: Barłogi, Barany (parafia Ostrowite), Brudnowo, Burzenin, Grabówka, Budzisław Kościelny, Ciechocinek (rozbudowa istniejącej świątyni), Ciepień, Cetty, Choceń, Chwalborzyce, Dobre, Golina, Janiszewice, Posoka (parafia Janiszew), Niewiesz, Kaczki, Kalisz (parafie: Miłosierdzia Bożego, św. Barbary i Najśw. Maryi Panny Królowej Polski), Koło (parafia Matki Bożej Częstochowskiej), Konin (parafie: św. Maksymiliana, św. Teresy,

${ }^{2}$ Np. informacja w kalendarzu z 1968 r.: „2 listopada odwiedziłem matkę i siostry. Przekazałem im [tu wielkość wsparcia]".

${ }^{3}$ Zachowały się kalendarze: $\mathrm{z}$ lat 1963-1966, 1968 - niemające w sprawach finansowych większej wartości, z lat 1971-1985 zawierają wiele ciekawych wiadomości w tych sprawach. 
Najśw. Maryi Panny Królowej Polski), Kozy, Kuny, Lekarzewice, Lubicz, Ochle, Pyszków, Sierzchowo (parafia Raciążek), Samarzewo, Sieradz (parafie: Najświętszego Serca Pana Jezusa, Najśw. Maryi Panny Królowej Polski), Smólnik, Dąb (parafia Smólnik), Sompolno, Śmiłowice, Włocławek (parafie: św. Józefa, Najświętszego Serca Jezusowego, Najśw. Maryi Panny Królowej Polski, Najświętszego Zbawiciela, św. Maksymiliana, Ducha Świętego, Narodzenia Najśw. Maryi Panny i św. Jana), Zduńska Wola (parafia św. Antoniego). Budowano w tym czasie także nowe skrzydło gmachu Wyższego Seminarium Duchownego we Włocławku, dom emerytów w Michelinie, liczne plebanie i salki katechetyczne. Informacje dotyczące dotacji na te cele są dokładne $\mathrm{z}$ datami dziennymi i sumami wpłat zarówno w dewizach, jak i w polskich złotych. Czasami podają źródła pochodzenia, np. „z intencji binowanych”.

Oprócz budowy kościołów najczęściej wspierane przez bpa Zarębę było Wyższe Seminarium Duchowne, katedra, kolegiata w Kaliszu, dom emerytów, dom rekolekcyjny w Nieszawie, a później także parafia św. Jana Chrzciciela we Włocławku. W notatnikach bpa Zaręby nie brakowało zapisów o wsparciu dla budowanych kościołów w innych diecezjach, np. w Inowrocławiu", Bydgoszczy $^{5}$, Gnieźnie ${ }^{6}$ o ofiarach na kolegiatę w Pułtusku, na budowę „Księżówki” w Zakopanem, wpłatach na sekretariat Episkopatu Polski itp.

W każdym roku znajdujemy wiele zapisów szczegółowych dotyczących wsparcia dla różnorakich akcji charytatywnych i pomocy charytatywnej dla ubogich, np. „na kolonie dla ubogich dzieci”, „dla kleryków na akcję charytatywną", „na kolonie letnie”, „na powodzian w olsztyńskim” w 1983 roku, na powodzian w diecezji włocławskiej w 1979 roku w parafiach: Kramsk, św. Wojciecha w Koninie, Kościelec Kolski, na różne akcje charytatywne bardzo często powtarzały się zapisy: „na ubogich”.

Odrębnym zagadnieniem była pomoc finansowa dla różnych zakonów, zwłaszcza kontemplacyjnych, ale nie tylko. Znajdujemy zapisy o wsparciu sióstr zakonnych eucharystek, karmelitanek ${ }^{7}$, westiarek, kamedułek i Wspólnej Pracy. Biskup łożył też na szereg innych celów: na orkiestrę, na chór katedralny, na chór klerycki, na ministrantów na ręce ich moderatora, dla archiwum w katedrze, na Klub Inteligencji Katolickiej, na puszkę do szpitala, na wsparcie Studium Rodziny, na sacrosong, na rekoronację obrazu św. Józefa, na duszpasterstwo akademickie, na oazy, na pomnik Kordeckiego w Iwanowicach, dla pracowników kurii na święta, na „Ateneum Kapłańskie”, na misje, dla misjonarza ks. Henryka Kowalskiego, opłaty za konwikt dla księży studentów wysłanych

${ }^{4}$ Kalendarz na rok 1983, suma 50000 zł.

${ }^{5}$ Kalendarz na rok 1978.

${ }^{6}$ Kalendarz na rok 1976.

${ }^{7}$ Dla sióstr karmelitanek biskup J. Zaręba zakupił plac i dom, który stał się podstawą tworzenia wspólnoty zakonnej. 
na studia przez diecezję itp. W zapiskach znajdzie też badacz wpłaty biskupa na Kurię Diecezjalną. Niech one nikogo nie dziwią. Często kuria musiała wydać więcej pieniędzy, niż miała wpływów. Stąd biskup uzupełniał wpływy kurii o swoje dotacje.

Mamy w kalendarzach także zapiski i wyliczenia ogólne, na przykład:

1) wpływy z intencji binowanych: w 1978 roku - 340000 zł, w 1979 $350000 \mathrm{zl}^{9}$, w 1980 - $520000 \mathrm{zt}^{10}$, w 1981 - $890000 \mathrm{zl}, \mathrm{w} 1982$ 1078000 zł i w 1983 - 1015000 zł;

2) spis wysokości ofiar złożonych na ręce biskupa przez księży z racji różnych posług: w 1977 roku - 1593000 zł, w 1978 - 1255000 zł oraz z racji 15-lecia biskupstwa 492700 zł, w 1979 - 1421000 zł, w 1980 - $2623000 \mathrm{zl}^{11}$, w 1981 - 3659000 zl, w 1982 - 2959000 zl;

3) faktyczny wykaz wpłat poszczególnych parafii na misje, a nie tych, które księgowano. Wpłaty osobiste księży na misje są odnotowane w kartotekach poszczególnych księży, zwłaszcza z czasów, kiedy te sprawy prowadził bp Czesław Lewandowski i bardzo dokładnie zapisywał te składki.

Tabela 2. Wydatki na budowę kościołów do 1985 roku $^{12}$

\begin{tabular}{|c|l|r|}
\hline \multicolumn{1}{|c|}{ Lata } & \multicolumn{1}{|c|}{ Kościół (lub inna budowa) w miejscowości } & \multicolumn{1}{c|}{ Suma } \\
\hline $1974-1985$ & Włocławek - św. Józefa & 17.452 .000 \\
\hline $1981-1985$ & Włocławek - Najśw. Serca Jezusowego & 13.675 .000 \\
\hline $1982-1985$ & Włocławek - Najświętszego Zbawiciela & 10.870 .000 \\
\hline $1978-1985$ & Włocławek - Najśw. Maryi Panny Królowej Polski & 15.670 .000 \\
\hline $1982-1985$ & Włocławek - św. Maksymiliana & 10.500 .000 \\
\hline $1982-1985$ & Włocławek - Ducha Świętego (Michelin) & 6.400 .000 \\
\hline $1984-1985$ & Włocławek - Najśw. Maryi Panny i św. Jana Ew. & 7.940 .000 \\
\hline $1973-1985$ & Kalisz - Miłosierdzia Bożego & 10.170 .000 \\
\hline
\end{tabular}

${ }^{8}$ Biskup nie płacił za utrzymanie księży studentów, którzy studiowali na własną prośbę (nie byli wytypowani na studia przez biskupa). Wprawdzie wszystkich kapłanów studentów prosił o napisanie podania o pozwolenie na odbycie studiów specjalistycznych, ale to nie przeszkadzało mu stosować powyższego rozróżnienia.

${ }^{9}$ Biskup przeznaczył je na: misje - 120000 zł, budowę kościołów - 100000 zł, cele charytatywne - 80000 zł, dom rekolekcyjny w Nieszawie - 50000 zł.

${ }^{10}$ Zostały przeznaczone na: misje - $150000 \mathrm{zl}$, budowę kościołów - 140000 zł, dom rekolekcyjny - 30000 zł, budowę seminarium - 50000 zł, akcję charytatywną - 150000 zł.

${ }^{11}$ W kalendarzu na 1980 r. jest adnotacja, że przeznaczono je na budowę kościołów.

${ }^{12}$ Ostatni zachowany kalendarz pochodzi z 1985 r. Ostatniego nie udało się odnaleźć. Do poniższych sum należy doliczyć jeszcze składki, jakie zbierała diecezja na budowę kościołów. 
Cd. tabeli 2.

\begin{tabular}{|l|l|r|}
\hline \multicolumn{1}{|c|}{ Lata } & \multicolumn{1}{|c|}{ Kościół (lub inna budowa) w miejscowości } & \multicolumn{1}{c|}{ Suma } \\
\hline $1982-1985$ & Kalisz - św. Barbary (Szczypiorno) & 6.800 .000 \\
\hline $1983-1985$ & Kalisz - Najśw. Maryi Panny Królowej Polski & 3.370 .000 \\
\hline $1983-1984$ & Konin - Najśw. Maryi Panny Królowej Polski & 500.000 \\
\hline $1980-1985$ & Golina & 9.340 .000 \\
\hline $1982-1985$ & Sieradz - Najśw. Serca Pana Jezusa & 9.925 .000 \\
\hline $1981-1985$ & Cetty & 8.145 .000 \\
\hline $1983-1985$ & Lubicz & 5.390 .000 \\
\hline $1981-1985$ & Śmiłowice & 5.100 .000 \\
\hline $1981-1984$ & Pyszków & 3.550 .000 \\
\hline $1982-1985$ & Lekarzewice & 4.550 .000 \\
\hline $1984-1985$ & Ciepień & 1.825 .000 \\
\hline $1983-1985$ & Kozy & 1.450 .000 \\
\hline 1984 & Janiszewice & 500.000 \\
\hline $1983-1985$ & Kaczki & 980.000 \\
\hline 1985 & Ciechocinek - rozbudowa & 1.300 .000 \\
\hline $1977-1985$ & Włocławek - seminarium - rozbudowa ${ }^{1}$ & 50.910 .000 \\
\hline $1983-1985$ & Włocławek-Michelin - Dom Emerytów ${ }^{2}$ & 12.550 .000 \\
\hline
\end{tabular}

Był to zapewne niemały wysiłek diecezji i biskupa przy takiej liczbie budujących się kościołów, np. w 1983 roku diecezja przeznaczyła na budujące się kościoły 30900000 zł i na pomoc innym kościołom 2210000 zł ${ }^{13}$.

Powyższe zestawienia nie wyczerpują wszystkich dotacji biskupa Zaręby. Do tego należy doliczyć pomoc udzielaną różnym parafiom z racji nadzwyczajnych potrzeb, np. wsparcie dla parafii: Brudzew Kaliski, Brudnowo, Czarne, Dobrzec, Głuchów, Izbica, Niewiesz, Ostrowąs, Lipe, Lubstówek, św. Jana we Włocławku (wielokrotne), św. Stanisława we Włocławku, dla katedry, na kupno działki pod kościół za Wisłą i na nowe ławki, Złotków. Zasiłki, jakich udzielał biskup, dotyczyły także poszczególnych księży będących w potrzebie, których biskup wspierał różnymi sposobami, zastrzegając najczęściej, aby obdarowany nikomu o tym nie mówił.

Mimo licznych informacji, jakie są zawarte w kalendarzach biskupa Jana Zaręby, są one jednak fragmentaryczne. Zapisy te, będące notatkami sumiennego rządcy diecezji, zapewne staną się najbardziej przydatne do opracowania jego działalności, a także szczegółowych dziejów budowy poszczególnych świątyń

${ }^{13}$ Adnotacja ręcznie zapisana przez bpa J. Zarębę w kalendarzu na 1982 r., na oddzielnej karteczce. Szczegółowych rozliczeń nikt jeszcze nie dokonał. 
lub działalności gospodarczych parafii oraz innych instytucji kościelnych. Dane do opracowania finansów kurii i diecezji w tych latach są za skromne, ze względu na brak rzetelnych i kompletnych zapisów dotyczących finansów Kurii i seminarium duchownego. Należy mieć nadzieję, że ktoś z osób odpowiedzialnych za finanse diecezji opisze w swoich wspomnieniach rzeczywiste sposoby finansowania jej działalności w tych czasach. Do pisania o tym, oprócz informacji poufnych, potrzebna jest także dobra znajomość ówczesnych realiów, o którą coraz to trudniej u młodych historyków.

\section{NEW SOURCES FOR FINANCIAL REASEARCH IN THE DIOCESE OF WŁOCŁAWEK DURING THE RULE OF THE BISHOP JAN ZARĘBA}

\section{SUMMARY}

There are very little sources available regarding Church's finances during the time of Polish People's Republic. Short drafts and notes made by bishop Jan Zaręba in his personal diary are exemplary exception. Nevertheless these notes are rather fragmentary, incomplete, and as such they may only partially illustrate complexity of the problem referred above. These notes and drafts, made by bishop Zaręba as a ruler of the diocese Włocławek, may serve for further studies of his activity, especially in the field of the churches building and other forms of economic activities of parishes and other ecclesiastical institutions.

Financial files collected in the Diocesan Curia are incapacious to give full and real evidence of financial income and expenses. This is due to lack of clear and complete rules regarding the financial policy in Curia and Diocesan Seminary.

Author of the article above expresses his wish and hope that one day someone responsible for diocesan economical policy in that time may describe more fully the ways and methods of financial management in the diocese of Włocławek. 